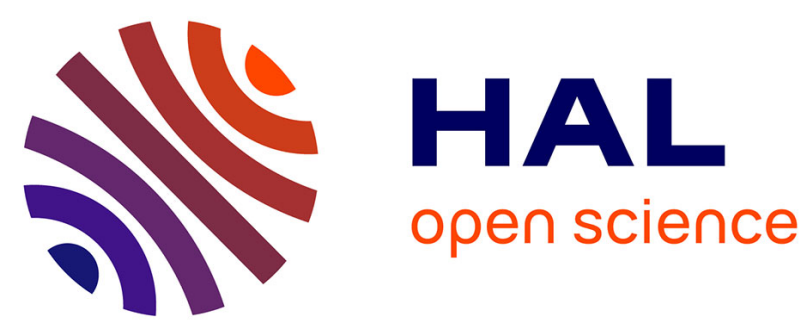

\title{
Diversity of farmland management practices (FMP) and their nexus to environment: A review
}

\author{
Yannick Dongmo Zangue, Romain Melot, Philippe Martin
}

\section{To cite this version:}

Yannick Dongmo Zangue, Romain Melot, Philippe Martin. Diversity of farmland management practices (FMP) and their nexus to environment: A review. Journal of Environmental Management, 2022, 302 (Part B), pp.114059. 10.1016/j.jenvman.2021.114059 . hal-03430589

\section{HAL Id: hal-03430589 \\ https://hal.inrae.fr/hal-03430589}

Submitted on 15 Dec 2021

HAL is a multi-disciplinary open access archive for the deposit and dissemination of scientific research documents, whether they are published or not. The documents may come from teaching and research institutions in France or abroad, or from public or private research centers.
L'archive ouverte pluridisciplinaire HAL, est destinée au dépôt et à la diffusion de documents scientifiques de niveau recherche, publiés ou non, émanant des établissements d'enseignement et de recherche français ou étrangers, des laboratoires publics ou privés.

\section{(ㅇ)(1) $\$$}

Distributed under a Creative Commons Attribution - NonCommercial - NoDerivatives 44.0 
Title: Diversity of farmland management practices (FMPs) and their nexus to environment:

\section{A review}

\section{Abstract}

We examined the environmental impacts of farmland management practices (FMPs), considering FMPs as frequent or single actions that change both land use AND use rights (land and property relations). Based on a review of the international literature in both the social and life sciences and using an analytical framework of landscape agronomy, we explored the links between FMPs and changes in agricultural practices designed for the achievement of environmental goals. The Web of Science (WOS) and SCOPUS bibliographic databases were used to identify references on FMP types and their environmental effects based on the following search equations: 1- " Farmland tenure OR cropland tenure OR farm size and environment " and 2- "Farmland use rights OR farmland property rights AND environment OR pollution OR biodiversity." Ninety references were selected from these databases and read in depth. Google scholar enabled us to identify an additional 20 papers, using the snowball approach. From this analysis, we present a typology of FMPs based on the distinction between bottom-up strategies, which rely on local initiatives from farmers to improve the overall functioning of their farms, and top-down strategies, which originate from public bodies or private organizations. Our results also highlight the environmental impacts of FMPs considered in the literature: tenure arrangements, whether rental or exchange of land parcels, may alter crop succession and reduce phytosanitary pressure without changing cropping plans. Considering the direct agronomic implications of farmers' land dynamics, we conclude that the area of FMPs is a potential tool for reducing the environmental impacts of agricultural activities and protecting natural resources. This is the subject of ongoing research that seeks to explore a particular FMP in greater depth, along with temporary exchanges of plots between farmers as an agri-environmental tool to reduce agricultural impacts on environment.

Keywords: farmland management practice, environmental impact, farmland use rights, farmland property rights 


\section{Introduction}

Preserving farmland and reducing the ecological footprint of agriculture is of global concern (Buskirk and Willi 2004; Silva et al. 2010; Foley et al. 2011; Alavoine-Mornas and Girard 2016). For example, the concern over degradation of agricultural soils led to the recent recognition of the importance of farmland management in the preservation of biodiversity (Binot and Karsenty 2007; Bertrand and Duvillard 2016). Another example is that European public policy has been gradually shifting toward reducing the agricultural pressure on ecosystems (Jepsen et al. 2015). Also, scenarios designed to preserve ecosystems focus on the protection of water resources and landscape management (Millennium Ecosystem Assessment in Leemans and Groot 2003).

Much of the academic research into environmentally sound agricultural practices that is done from an agronomic perspective focuses on the design of the cropping system (crop diversification, optimization of agricultural practices, extension of crop rotation, and others) or on the management of pasture (Steinmann and Dobers 2013; Davis et al. 2012; Foley et al. 2011; Ribeiro et al. 2016). These studies are made at the scale of the agricultural plot or plot cluster, which are considered stable units. However, studies conducted from the perspective of landscape agronomy highlight the dynamics of permanent transformation of farm plots and farming landscapes; these dynamics result in successive phases of growth, reduction, or reconfiguration (Wästfelt and Zhang 2018; Barbottin et al. 2018; Preux 2019). Such dynamics can alter the cropping system and affect the environment (Steinmann and Dobers 2013). Better understanding of these effects on the cropping system and environment would permit the identification of new tools to preserve the environment in agricultural systems. Any such tools must take into account how the farmers' property rights affect the link between agricultural production and environmental preservation (Beyene et al. 2006; Gueringer 2019).

In this study, we designate "farmland management practices" (FMPs) as farmers' decisions that are based both on the dimensions of farming design and management of property rights (Sklenicka et al. 2015; Calo and Master 2016; Sklenicka 2016a). Indeed, upstream of technical concerns, farmers assess the resources at their disposal, particularly land resources, and develop diversified strategies relating 
to property rights (Holtslag-Broekhof et al. 2014). Depending on their investment capacity and opportunities to access land, they arbitrate between farm tenancy, ownership, (Boinon 2013), illegal land occupation (Lipscomb and Prabakaran 2020), or even plot exchanges (Lucas et al. 2015). Thus, FMPs differ from one farmer to another according to the constraints each farmer faces.

Agriculture must be deeply concerned with biodiversity conservation (Jepsen et al. 2015). It is, therefore, necessary to consider FMPs from an environmental perspective if one wishes to identify perspectives for a sustainable management of natural resources in farming (Bertrand and Duvillard 2016). We propose to identify the mechanisms by which farmers manage their farmland in relation to their land-use rights and how these mechanisms impact the environment.

Here, we have performed a literature review of FMPs and present an overview of diversity of the aforementioned mechanisms. We also discuss the links between FMPs and changes in agricultural practices that have been designed to meet environmental goals. We will address two questions. These are: i) what are the main types of FMPs in the literature? and ii) How are the environmental consequences of FMPs considered in the literature about FMPs? We hypothesized that the type of FMP will depend on whether it originated from farmers' choices or from public or private policies. These FMPs are likely to affect the environment.

We have adopted an interdisciplinary approach, interweaving agronomy and sociology to analyze the diversity of FMPs.

We have organized the document into six sections. In Section 2, we briefly review the concept of FMPs and explain our approach. In Section 3, we discuss the working methodology that we adopted. In Section 4, we propose a typology of FMPs and illustrate it with examples taken from the literature. In this section, we also discuss the possible environmental consequences of FMPs. In section 5, we conclude by looking forward to new environmental research opportunities. Finally, we present some limitation of the study.

\section{Conceptual framework}


A precise definition for FMPs is useful. In this study, we consider an FMP as an action or frequent actions that leads to changes in both land use and land-use rights. These actions may be carried out by a farmer, a group of farmers, or public authorities. Farmers may act independently or collectively-the latter usually in the context of shared projects, and within the confines of the law. The actions may be at the scale of an individual farm or of a group of farms and are likely to impact the organization and implementation of technical systems.

The definition for FMP adopted above addresses the junction between property rights and actual land use from the point of view of the actors involved (Gueringer 2019). Through an action, a farmer seeks to ensure the nature, whether temporary or permanent, of agricultural uses on land (Le Roy 1991; Deaton et al. 2018) and implement his technical operations. The way in which the farmland portfolio is accessed and managed will therefore be a determining factor in carrying out technical operations (Beyene et al. 2006).

The concept of FMP developed here is distinguished from agricultural practices by the fact that it integrates both the social or even societal dimension and the agricultural dimension. The social dimension refers to the strategies that farmers put in place to secure the right to use or own the land they bring into production and the interactions that take place between the various actors involved with it. The agricultural dimension refers to the agricultural use of the land, which is often the implementation of agricultural techniques by the farmers.

Before production begins, farmers integrate their relationship with the land, particularly the sustainability of access to it. They consider the future of their plots in the short-, medium-, and long term and the measures to be taken to secure them. Depending on their investment capacity and the opportunities to access land (e.g. to acquire land that was taken over following disposals), they may arbitrate between different modalities such as leasing, acquisition, or taking stakes in companies (Boinon 2013; Sklenicka 2016a). This may give rise to extension strategies, but also to internal 
restructuring strategies that vary from one farm to another (Melot 2014). For instance, to reduce the distances between the different plots, maintain crop rotation, or bring the plots closer to the farm's headquarters, farmers may exchange plots with other farmers when the environment is favorable (Gedefaw et al. 2019). A similar example is the expansion of farm surfaces by acquiring adjacent plots and by leveling internal plot boundaries (Doré et al. 2006). The decision on the production mode, whether low input or intensive, can also be influenced by the farmer's land-tenure situation, that is, his degree of land-tenure insecurity (Sklenicka et al. 2015; Akram et al. 2019).

The insecurity of land tenure may be inherent in a land-lease contract when land tenure is precarious and is also a factor in the willingness of farmers to invest in conservation (Reid et al. 2000; Gao et al. 2012; Sklenicka 2016). For example, a farmer who is operating without land ownership and holds a precarious lease contract may not take measures to protect the soil, plant trees, or improve pastures because there may not be enough time to ensure a return on investment ( $X u$ et al. 2014; Choumert and Phélinas 2015; Deaton et al. 2018). On the other hand, where the lease is long term and protected by law, the farmer may be willing to make production-related investments in the leased land (Wästfelt and Zhang 2018). Thus, a property system that favors land ownership by farmers should increase the farmer's incentive to invest in his farm due to a low risk of expropriation (Lipscomb and Prabakaran 2020). Land ownership is also involved in the choice of equipment and the organization of work through the dispersion and location of plots (Morardet 1995).

\subsection{What are the determinants of FMPs?}

As mentioned in Section 2.1, farmers acquire land use or ownership rights in different ways. Generally, FMPs are determined by the structure and functioning of the farm, which are subject to different constraints (Fig. 3) that we considered as internal or external.

Internal constraints are imposed by the structure of the farmland, which includes plot size, land fragmentation, distance between plots, distance from the plots to the farm headquarters, accessibility, and the feasibility of crop management, which includes breaking the weed cycle, respecting return 
deadlines, and managing rotations. Such internal constraints can interfere with the implementation of the farmer's farming practices (Fig. 3), resulting in a reorganization of the farm's territory through farmland management.

External constraints represent environmental constraints, such as climatic variations and soil quality, and socio-institutional constraints, such as public policies, land market, the land regulations imposed, and the social environment. These constraints may lead the farmer to improve the characteristics of his plots to meet his production requirements. Depending on his production goals, he may adopt practices that enable him to reduce the impact of these constraints on his production. The choice of a land-based tool will be based on the perceptions of the different land-use rights situations that arise.

\section{Material and methods}

\section{Collection of secondary data and reviewed publications}

We tested the hypothesis that the type of FMP depends on its origin: whether from farmers or from public or private policies. We performed a literature review following the guidelines formalized by Hagen-Zanker and Mallett (2013). Specifically, we asked what the options were for farmers to dispose of temporary- or permanent-use rights on farmland and the environmental consequences of these options.

We used Web of Science (WOS) and SCOPUS databases to identify articles relating to FMPs and the environment. We chose these databases as they contain a wide range of references in different disciplines, including agronomy, sociology, and ecology. We conducted two bibliographic searches at different time periods. The first bibliographic searches were carried out from November 20 to December 6, 2019, in SCOPUS and from December 7-13, 2019, in WOS.

Queries were performed in English using a series of keywords and combinations of keywords defined in advance. The following search equation: " Farmland tenure OR cropland tenure OR farm size and environment " was used to query the WOS and SCOPUS databases for items. With this first selection, we obtained 8,879 papers. We considered this a source of raw data and next refined it by manually 
screening each title and abstract. Papers that we selected met the following criteria: (1) the title of the paper had at least one of the keywords and (2) the abstract of the paper included keywords and discussion of "FMPs" or "farmland and environment." Papers that were in both databases, that is, duplicated, were identified and one duplicate was removed from the collection. No date restrictions were applied to searches. After applying the first criterion, 820 papers were selected, and after applying the second selection criterion, we obtained 75 papers from the two databases.

The second bibliographic searches were carried out from July 26-30, 2021, in SCOPUS and from August 10-15, 2021, in WOS. A new search equation: "Farmland use rights OR farmland property rights AND environment OR pollution OR biodiversity" was used to query the WOS and SCOPUS databases. We obtained a corpus of 624,951 papers. By applying the same approach as in the first search and after completing all the sorting steps, 15 papers were retained and added to the first 75 papers, yielding a final selection of 90 papers from the two databases.

In addition to WOS and SCOPUS, we drew on other sources for relevant papers. We used the snowball approach with Google scholar to identify an additional 20 papers. The snowball approach consists of reading a paper and searching its references for other relevant publications (Hagen-Zanker and Mallett 2013). Personal knowledge, discussions with colleagues and experts in the field, and the reading of others' literature (reports and unpublished studies) allowed us to broaden our thinking and identify other relevant papers.

\subsection{Data analysis}

The selected papers were then subject to an in-depth reading and content analysis. We developed a thematic analysis grid based on the main elements emerging from a careful reading of the corpus of papers. Our goal was to classify FMPs according to their types, creating a typology. We identified the theme of each paper: FMPs based on farmers' initiatives (38 articles), FMPs related to the implementation of public policies ( 63 articles), and others ( 9 articles). These papers can be found in an Additional file. Figure 1 describes the various stages of the literature search and data analysis. 


\section{Step1: Bibliographic search in SCOPUS and WOS}

Search equation1: "Farmland and environment OR cropland tenure OR farmland tenure OR farm size and land consolidation»

$$
\text { References found }=8,879 \text { papers }
$$

Search equation 2: "Farmland use rights OR farmland property rights AND environment OR pollution OR biodiversity»

References found $=624,951$ papers

First sort: selection factor $=$ presence of at least

one keyword of the equation in the title.

Papers selected after title reading $=1,050$

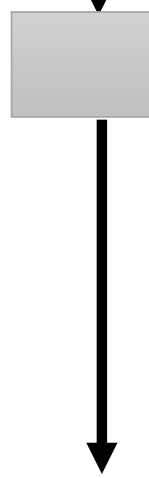

Step 2: Abstract reading

Second Sorting :

- $\quad$ selection factor = presence of keywords in the abstract and/or abstract not relevant to the theme

Exclusion of duplicates (87 papers were duplicated, that is, present in both wOS and SCOPUS)

Papers selected for further reading $=90$

Step 3: In-depth reading papers from WOS and SCOPUS (90 papers)

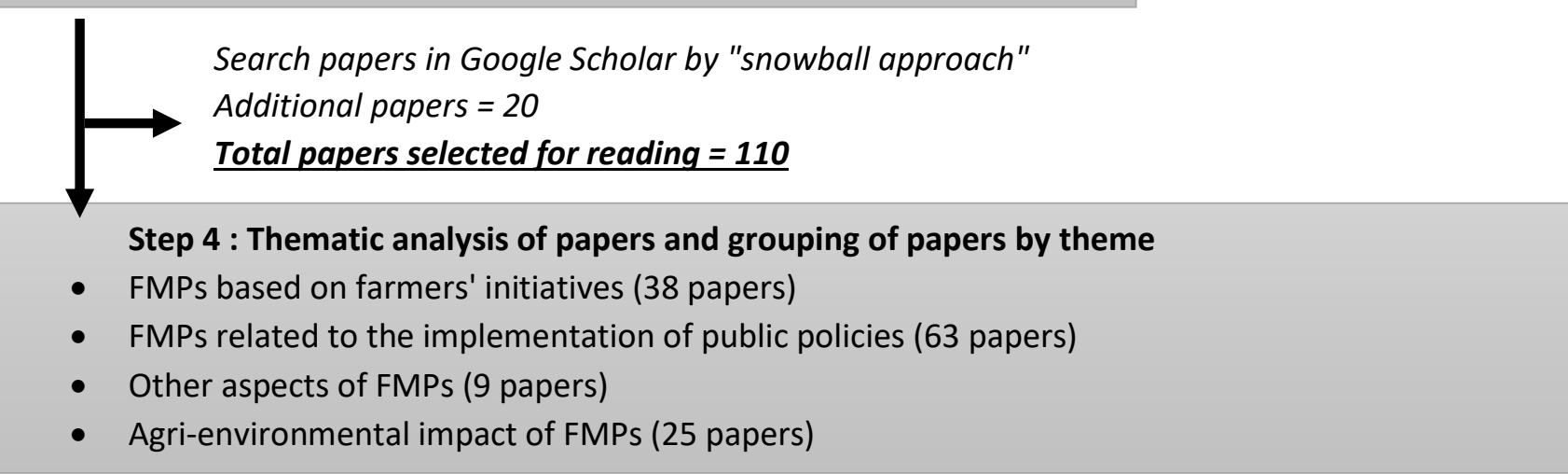


183

Table 1: Classification of the 110 papers consulted by FMP category and environmental issues addressed.

\begin{tabular}{lccc}
\hline \multicolumn{1}{c}{ Topic covered in the paper } & $\begin{array}{c}\text { No. papers in which } \\
\text { environmental issues } \\
\text { were addressed }\end{array}$ & $\begin{array}{c}\text { Total papers per } \\
\text { topic covered }\end{array}$ \\
\cline { 2 - 3 } & NO & Yes & \\
\hline $\begin{array}{l}\text { Policies instruments that change the structure of } \\
\text { the land tenure }\end{array}$ & 13 & 7 & 20 \\
$\begin{array}{l}\text { Policy instruments that impact user rights through } \\
\text { regulation }\end{array}$ & 38 & 5 & 43 \\
FMPs initiated by individual farmers & 22 & 6 & 28 \\
FMPs initiated by farmers collectively & 10 & 0 & 10 \\
$\begin{array}{l}\text { Others } \\
\text { Total paper per environmental issues addressed }\end{array}$ & 85 & 7 & 9 \\
& 2 & 25 & 110
\end{tabular}

\subsection{Overview of the distribution of FMPs in the selected papers}

The topics addressed in the 110 papers that we consulted and classified are presented in Table 1 . Papers dealing with policy instruments that impact user rights through regulation were the most numerous, with 43 papers referenced, and the next most numerous were papers dealing with FMPs initiated by individual farmers, with 28 papers referenced. Environmental issues related to FMPs were addressed for three out of four categories of agricultural land practices. No papers dealing with environmental impacts of FMPs initiated by farmers collectively were included in the list of selected papers.

The papers we consulted originated from 40 different countries on all continents (Fig. 2). Twenty-six papers were from China, the most from a single country. Twenty-two papers were from France, nine from the USA, five from Poland, and two each from the Czech Republic and Canada.

More than $75 \%$ of the papers were published less than 10 years ago, which may be evidence of growing interest in agri-environmental aspect of FMP. 
Table 2: Distribution of reviewed articles by field of study and keys issues addressed

\begin{tabular}{lrcr}
\hline \multicolumn{1}{c}{ Field of study } & $\begin{array}{c}\text { Did not include } \\
\text { environmental issues }\end{array}$ & $\begin{array}{c}\text { Included } \\
\text { environmental issues }\end{array}$ & Total articles \\
\hline Geography & 17 & 3 & 20 \\
Economics & 13 & 5 & 18 \\
Sociology & 9 & & 9 \\
Agroeconomy & 6 & 1 & 7 \\
interdisciplinary & 6 & 1 & 7 \\
Agronomy & 5 & 5 & 10 \\
Social sciences & 5 & 1 & 6 \\
Rural landscape & 3 & & 3 \\
management & & & 3 \\
Urban planning & 3 & & 2 \\
Ecology & & 2 & 6 \\
Environmental science & 2 & 4 & 3 \\
Political science & 2 & 1 & 2 \\
Socioeconomy & 2 & & 1 \\
Landscape agronomy & 1 & & 1 \\
Management sciences & 1 & & 11 \\
Mathematics & 1 & 2 & \\
Others & 9 & 25 & \\
Total & 85 & & \\
\hline
\end{tabular}

200

201

The table2 above shows the main scientific disciplines to which the papers in the corpus of literature consulted are related. About 7 disciplines account for $75 \%$ of the articles dealing with the environmental aspects of FMPs and $60 \%$ of all the articles consulted. Biodiversity is the main environmental issue most often addressed. Geography, economics and sociology are the first three disciplines most representative of the corpus of literature consulted. The environmental science disciplines seem to be less interested in the environmental aspects of agricultural land tenure practices, with only four articles. 
Table 3: Main data sources used in the different articles in the corpus of articles consulted.

\begin{tabular}{lrr}
\hline \multicolumn{1}{c}{$\begin{array}{c}\text { Methodological } \\
\text { features }\end{array}$} & Total & Pourcentage \\
\hline $\begin{array}{l}\text { General data bases analysis (Land } \\
\text { register; Geographic Information }\end{array}$ & 34 & 30.9 \\
System; socio economic data) & & \\
Interviews & 15 & 13.6 \\
Modelisation & 13 & 11.8 \\
Literature review & 8 & 7.3 \\
Field surveys & 9 & 8.2 \\
Policy analysis & 6 & 5.5 \\
Position paper & 6 & 5.5 \\
Case study & 2 & 1.8 \\
Data surveys & 1 & 0.9 \\
Archives.field surveys & 1 & 0.9 \\
Landscape observation & 1 & 0.9 \\
Life cycle assessment & 1 & 0.9 \\
Mail survey & 1 & 0.9 \\
Media info and web data & 1 & 0.9 \\
Spatial analysis of & 1 & 0.9 \\
landscape & & \\
Others & 10 & 9.1 \\
Total & 110 & 100 \\
\hline
\end{tabular}

217 modelling of GIS data or general databases (land register or agricultural census). This highlights the

218 need for more field data collection (interviews, surveys, on-site observations). 
220

221

222

223

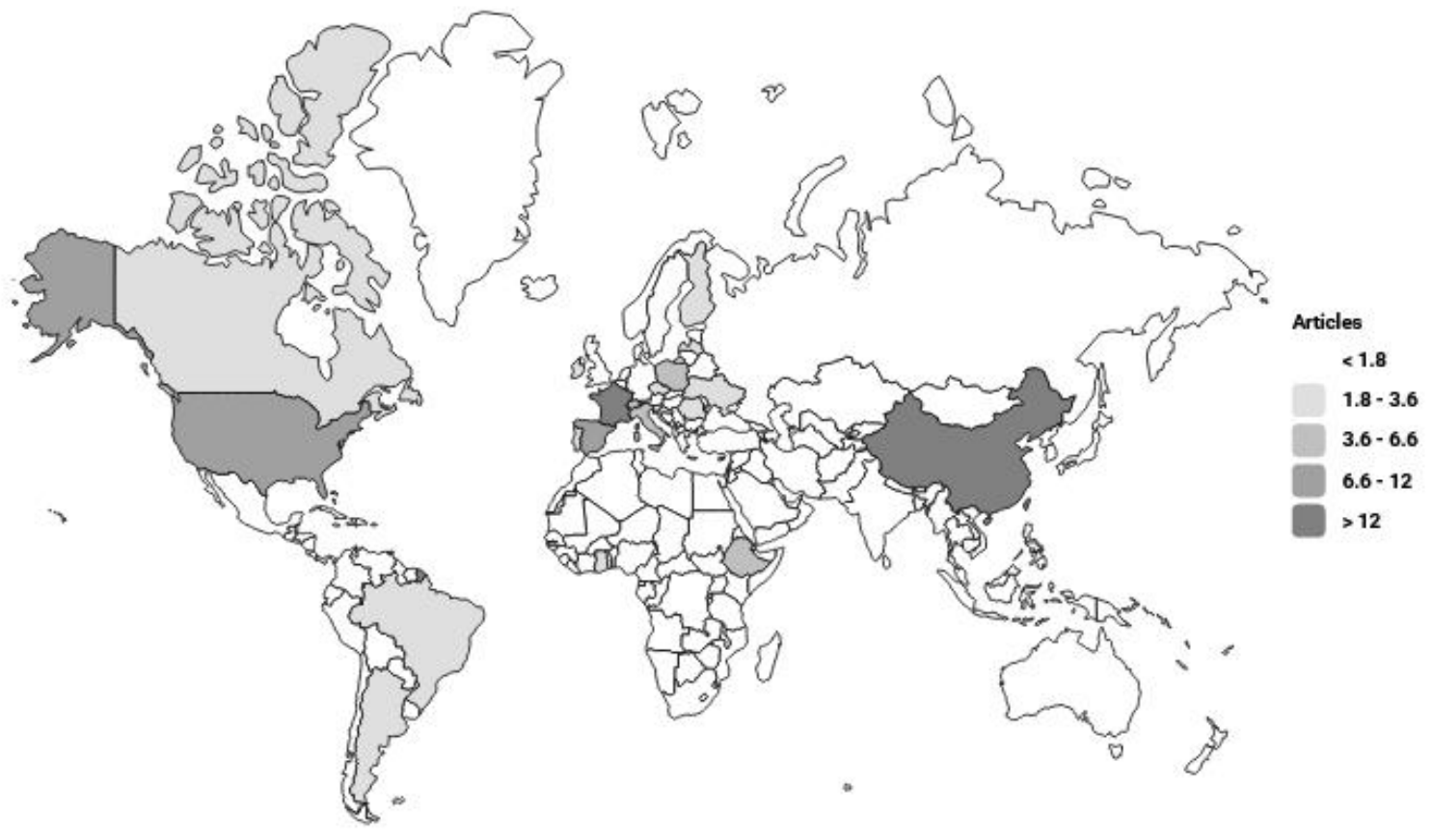

Figure 2. Geographical distribution of papers related to FMPs.

The overview of this literature review helped us to establish the typology of FMPs. Particularly, we distinguish here between bottom-up strategies, which originate from local initiatives from farmers, and top-down or implementation strategies, which originate from public bodies or private organizations. This FMP typology is presented in Section 4.2 below.

\subsection{Typology of FMPs}

In this section, we present a typology of FMPs. The type of FMP is defined based on whether it is (i) a bottom-up strategy based on local farmers' initiatives to improve the overall functioning of their farms or (ii) implementation of top-down strategies that are imposed by public bodies or private organizations. The first category of FMP is divided into subcategories according to whether the action is collective or individual. Within each sub-category, we distinguished types that differ by the strategies used to tackle the constraints hindering the operation of the farm. The second category (top-down strategies) is also divided into subcategories according to the effects of the strategies on property and land-use rights. 
a) Purchase of land-use rights to improve the farming technical system or the land structure

In this situation, the farmer faces difficulties related to the internal functioning of his farm. He seeks

to improve his production system or to improve the topology ${ }^{1}$ of his farm through such strategies as enlargement, maintenance, or reduction.

According to several authors, when the farmer faces logistical constraints, he may be tempted to reconfigure his farmland holding ${ }^{2}$ in space and time. He may re-arrange his parcels in one of several ways. He could enlarge them, by linking the parcels together to form large islands in a single block, by merging the parcels and removing their physical boundaries such as hedges, or by purchasing new plots that might become available from neighboring farmers. He could also reduce the number of parcels by selling some. Another option for re-arrangement of his parcels would be to agree with his neighbor to exchange or rent the parcels. Reconfiguring the farmland resolves a structural constraint, and the solution that is provided is generally long term or even definitive. In the literature, the practices of grouping parcels with parcels that are close to the farm's headquarters or of exchanging plots between farmers have been highlighted in Rwanda (Nilsson 2019), France (Francart et Pivot 1998 ; Marie et al., 2009; Saint-Cyr et al. 2019), and the Czech Republic (Janovska et al. 2017).

When the farmer faces phytosanitary issues or must break the cycle of weeds, he may seek to temporarily move his crops to other land, leaving his land fallow to resolve the problem. He may rent

\footnotetext{
${ }^{1}$ For the farmer, the topology represents the relative position of the parcels in relation to each other and in particular in relation to the seat of the holding and other buildings of the holding, the relative size and shape of the parcels, as well as the structure of the access roads to his parcels.

2 I consider "farmlandholding" as all cultivated plots of land for which a farmer has the right of use or ownership.
} 
in the same location, which becomes problematic due to lower efficiency of chemical inputs.

259 Temporary rental of plots by farmers to meet agronomic constraints has been documented by Amblard 260 and Colin (2009) in Romania; Lucas et al. (2015) and Marie et al.,(2009) in France, and Choumert and Phélinas (2015) in Argentina.

When the farmer's objective is to reduce operating overhead costs, he may choose to regroup his parcels if they are dispersed or rent land. The latter seems to be the most accessible option, although it does not always guarantee a high degree of security on the land (Ciaian et al. 2012). Also, the distance between dispersed plots and the tractor travel necessary to reach them may prohibit their acquisition (Preux 2019).

\section{b) Purchase of land-use and property rights to adapt to external constraints}

The farmer seeks above all to minimize external risks, such variations in the climate that are likely to impact the operation of his farm. He uses the farmland as a lever or tool to adapt his production system to the external environment.

To cope with constraints due to climate, the farmer will seek to have plots of land in different environments to spread out production and minimize rainfall hazards. He will seek to acquire plots scattered over different zones to benefit from the variation in microclimates and soils within these zones, thereby reducing the constraints on crops. Some examples will serve to illustrate. Ethiopian farmers (Gedefaw et al. 2019) and French farmers in mountainous regions (Mottet et al. 2006) seek to own plots in both valleys and hills to take advantage of the ecological differences, to be able to allow for complementary production (e.g. crops and meadows for breeding). In the states of Oregon and Idaho, in the USA, Zhang al. (2018) suggest that climate change leads to larger and dispersed farms, which are more likely to address irregular crop yields

When the external constraint is competition for land from urban pressure, the farmer may try to make his land more secure. In some cases, he may invent new relationships with the land. An example in Sweden is described by Wästfelt and Zhang (2018). In this example, the farmers developed novel land 
leases called "side leases," in which they rented the land annually and re-negotiated the lease yearly. Similarly in France, Jarrige and Napoleone (2003) note that large agricultural companies in peri-urban areas address urban pressure for their land by extending and moving their plots frequently through short-term leases.

\section{c) Accessing rights to land use through conquest or clearing land}

This discussion generally applies to young farmers who seek access to land or to increase the size of a farm. This is a situation of land insecurity, in which the potential farmer does not have title deeds to the land he attempts to acquire (Lipscomb and Prabakaran 2020). In response, he develops strategies that enable him to occupy land and assert his right to farm it. An example of access to land-use rights by young farmers is described in northern Cameroon by Dounias (1998). In this case, the strategy adopted was to plow vacant land and plant it with cotton.

\subsubsection{FMPs initiated by farmers collectively}

\section{a) Sharing land-use rights between farmers}

This situation exists when there is no change of land ownership but rather direct interactions between either farmers or social organizations with collective or community management.

In the case of direct interaction, rights are reciprocally shared: the farmer who owns land joins forces with a second person, who manages it. For instance, an owner might authorize a herder to graze animals on the owner's plots after harvest or during inter-cropping. In return, the animals will keep the plot clean and the herds will deposit enriching manure on the land (Poinsot and Faure 2000). The owner may also be required to produce fodder (in this case, alfalfa-type protein fodder) so that the herder does not lack fodder, and in return, the herder is expected to regenerate the soil, specifically, controlling weeds, improving soil structure, and enhancing its fertility.

Situations also occur in which an owner grants the right to use land to another farmer under a verbal or written arrangement (Horst 2019). The delegation of use rights usually do not entail an intrinsic 
right of access to the land (Colin and Tarouth 2017) and are usually between farmers who know each other or who share the same social network (Clément et al. 2019; Keeley et al. 2019a). The owner may be remunerated with a share of the harvest (sharecropping) or by receiving a lump sum (tenant farming). He may also reserve the right to use certain parts, such as hedges or an irrigation network, in his own operations. We found this practice in the USA (Horst 2019; Keeley et al. 2019a), Canada (Magnan 2015; Rotz et al. 2019), and France (Poinsot and Faure 2000; Clément et al. 2019).

If we consider collective forms of land management, the community is the owner and ensures each member of the community the right to use the land. Rules are established to resolve conflicts. An example is a grazing reserve, called a "vain pasture" in France and "jiindo de pasto" in the semi-arid Nordeste region in the northern part of the Brazilian State of Bahia. This reserve is an open space for the collective use of natural resources that is used for communal grazing and is a resource for all members of the community, not only for fodder, but also for wood and gathering (Sabourin et al., 1995). Another example is the commonage in Ireland. A commonage is land held in common ownership on which two or more farmers have grazing rights (Van Rensburg et al. 2009). In West Africa, this mode of land management is present in complex ecosystems such as the Inner Niger Delta, where land is often alternately flooded and cleared. Different users share land-use rights, sometimes at different times (Binot and Karsenty 2007). When land management is community based as well as in China, the community that holds the property rights grants farmers temporary land-use rights (W. Hu 1997; Yang et al. 2020).

\section{b) Pooling of land-use rights to meet a common goal}

In this scenario, there is no change of ownership, but rather a mutual commitment of resources, such as land, supplies, or equipment, to meet a common goal. An example of a common goal might be to reduce fixed costs. How temporary the project is will determine the farmer's level of investment and his contribution of land-use rights. In a joint project of relatively short duration, investments will likely be limited to exchanges of materials, group purchases of supplies and their storage, or sale of crops. 
duration, the farmers may invest in the purchase of equipment, and in this case, the pooling of landuse rights may be more long term or permanent. In France, joint crop rotation results in plots of land being considered as a single unit, but the farms involved are not merged. As mentioned by Gabriel et al. (2019), this kind of cooperation can increase productivity because farmers can cultivate several contiguous plots of land in one block and save time and work. It is possible for them to set up farming areas where they can bring work sites closer together and significantly reduce mechanization costs (Gabriel et al. 2019).

\section{c) Delegation of land-use rights to agricultural management companies}

Farmers, whether landowners or tenants, may entrust the management of their farm to agricultural contractors. These service providers may control all or only part of the production process, allocating crops to plots and overseeing cultivation. When the service provider has a sufficiently large customer portfolio, he can set up an organization that enables him to manage all the farms he is responsible for in a homogeneous manner. Each farm ultimately represents only one element of a much larger farm, entirely managed by the contractor. Farm work companies are particularly appealing to farmers in certain situations, such as farmers nearing retirement or not wishing to renew equipment.

According to Nguyen and Purseigle (2012), the use of agricultural contractors is a consequence of families with a long history of farming who are unable to continue farming themselves but are unwilling give up their farm. The increasing use of contractors is a contentious issue, as it may create barriers for the entry of interested parties into agriculture: contractors and young farmers hoping to start their farms may be in competition for land (Anzalone and Purseigle 2014). Management of farms by contractors has been described in the USA (Horst 2019; Keeley et al. 2019a), the Czech Republic (Sklenicka et al. 2014), Canada (Magnan 2015), Africa (Colin and Tarouth 2017), and France (Cochet 2008; Anzalone and Purseigle 2014).

\subsubsection{FMPs based top-down strategies from public bodies or private organizations}

This discussion relates to policies that are implemented by public bodies, including local authorities, public or semi-public agencies, or private agencies, such as non-governmental organizations. These 
policies may consist of voluntary or mandatory regulations on farming activities, and they may directly or indirectly impact land use and land-use rights.

There are many public policy instruments that affect land use. Gerber et al (2018) identified four types of instruments of land policy, categorized by the nature of their regulation and effects on property and land-use rights. These are:

i) Type 1: policies with no impact on the content of use or disposal rights,

ii) Type 2: policies with an impact on the scope and content of use or disposal rights,

iii) Type 3: re-definition of property rights with an impact on the scope and content of use or disposal rights, for example, tradable development rights, and

iv) Type 4: re-definition of the structure of the distribution of property titles.

According to this typology of policy instruments, Type 1 refers to voluntary regulations and incentives that are limited to changes in farming practices (Legras et al 2016). Instruments of this type include agri-environmental measures, tax schemes, and common agricultural policy incentives. The implementation process of these instruments is well documented in the literature, particularly when economics are considered. Although these regulations may impact land values, they do not have a direct impact on property rights and, for that reason, we have not included papers that refer to this type of research here. Rather, we focused our survey on instruments of Type 2 and 3, which have an impact on use rights through regulation, and Type 4, which change the structure of the land-tenure system.

\subsubsection{Policy instruments that impact user rights through regulation}

These instruments consist of public policies implemented through Type 2 or 3 regulations [following the Gerber et al (2018) typology of land-use policy instruments]. Both sets of regulations affect property rights, and Type 3 regulations may have a major impact on property rights, even re-defining them. 
Among these policy instruments, we concluded that land consolidation was the most documented in the literature we consulted. Many researchers consider land consolidation as a tool for simplifying landscape management (Grammatikopoulou and Pouta 2013; Latruffe and Piet 2014; Luis OREA, et al., 2015; Nilsson 2019). It has been widely used in various contexts to reduce the fragmentation of land ownership (Luis OREA et al. 2015 ; Strek 2018) and to foster land exchanges as a tool for farm restructuring, especially when a large number of willing owners participate (Teijeiro et al. 2020; Gedefaw et al. 2019). In Poland and France, public policies promoting land consolidation have been implemented to expand farms and address the problems often associated with land fragmentation (small, irregularly shaped, or dispersed plots) (Gedefaw et al. 2019) and thus increase agricultural production (Latruffe and Piet 2014). In China, too, the policy of land consolidation on fragmented land has been widely promoted by the government (Yang et al. 2019).

Policy instruments may combine regulation and acquisition tools to impose constraints on agricultural activities in vulnerable natural areas. In France, zoning imposed by the government serves to protect environmentally sensitive areas, and land use is restricted and controlled. In these areas, building and industrial activities are prohibited, and farming activities are markedly constrained. Zoning regulations are sometimes combined with land acquisition by private estates to ensure the protection of the estate (Legras et al 2016).

In the USA, the "land-trust movement" is an example of a private initiative that affects land use, in this case, with an environmental objective. Land trusts acquire land to protect it and the local ecosystem (Parker 2004). In France, community land trusts acquire farmland to preserve its value for agricultural production in the long term and, in turn, lease them to farmers. Stipulations requiring organic and environmentally sound practices may be part of the contract (Léger-Bosch 2019).

Rather than an agency acquiring full ownership, it may attempt to conciliate farming activities and environmental protection by focusing on certain components in the bundle of rights held by the landowner (development of rights or right of use). For example, land trusts may acquire "conservation 
easements," which are contracts between a landowner and an easement holder that impose restrictions on all or certain plots held by the owner (Merenlender et al. 2004; Daniels 2020). In the US, programs for ecological conservation concentrate on the purchase of conservation easements. According to Stoms et al. (2009), these programs have enabled the US government and public sector to preserve approximately 730,000 ha of agricultural land. In France, agreements that are equivalents to conservation easements in common-law countries were introduced into national law in 2016. "Real Environmental Obligations" (REOs) are land-based tools that can be used in environmental preservation programs. They are contractual instruments that link permanent obligations to a property. They are intended to protect the environment and are binding into the future, and to future landowners. This contractual mechanism helps to maintain, conserve, manage, or restore biodiversity elements or ecological functions.

Conservation easements are often part of ecological compensation policies. Ecological compensation consists of securing land by means of sustainable acquisitions or agreements and restoring it through ecological actions, with the goal of increasing its value (Etrillard and Pech 2015). This tool is still being tested in various countries, although it seems to be well developed in the USA.

Another policy instrument often used by different states is expropriation. This concerns the transfer of property rights of the original parcel from the landowner to a state (Gerber et al 2018). In France, as part of the process of restoring water catchments that are most threatened by diffuse pollution of agricultural origin, policies on property management allow local authorities to purchase agricultural land by expropriation or by mutual agreement. The original use of the land may change, and it will be used for agri-environmental purposes (Barataud et Hellec 2015 ; Lamoureux 2016).

\subsubsection{Policies instruments that change the structure of the land tenure}

These policy instruments are Type 4 in the Gerber et al (2018) typology. They can radically re-define the structure of the distribution of property titles and are usually part of major reforms. They may operate at different territorial scales. 
433 Land reform can be a major public policy instrument with considerable impact on property rights. For 434 example, in China, Hu (1997) considered that the post-Mao rural reform of the early 1980s had taken 435 over the collective management rights of land by giving the farmers the right to use the land but failed 436 to provide a clear property regime for both owners and users of the farmland. According to this author, 437 despite the growth of Chinese's agriculture, the country's agri-environment has been widely degraded 438 since the implementation of the reform due to short-sighted decisions and the irresponsible use of 439 land resources. Land reform in Albania was done by redistributing the land on a per capita basis, 440 according to Sallaku et al. (2016). Each family received equal amounts of arable and non-arable land, 441 fruit trees, vineyards, and olive trees.

442 Table 4 below summarizes the types and characteristics of the FMPs identified in the literature we 443 consulted. 
Table 4: Farmland management practices (FMPs) identified in the literature.

\begin{tabular}{|c|c|c|}
\hline Determinants of FMPs & Type of FMP & Examples of FMPs \\
\hline \multirow[t]{2}{*}{ Agronomic constraints } & \multirow[t]{2}{*}{$\begin{array}{l}\text { Purchase of land-use rights to improve the farming } \\
\text { technical system or the land structure of the farm }\end{array}$} & $\begin{array}{l}\text { Grouping of plots with leveling of hedges or purchase of } \\
\text { neighboring plots }\end{array}$ \\
\hline & & Temporary exchanges of plots \\
\hline \multirow{3}{*}{$\begin{array}{c}\text { Environmental constraints } \\
+ \\
\text { Constraints linked to the } \\
\text { farm topology }\end{array}$} & \multirow{3}{*}{$\begin{array}{l}\text { Purchase of land-use and property rights to adapt to } \\
\text { external constraints (climatic, urban pressure with } \\
\text { competition on land) }\end{array}$} & Plot leasing \\
\hline & & Plot fragmentation (acquisition of dispersed plots) \\
\hline & & Purchase or sale of plots \\
\hline \multirow[t]{2}{*}{ Environmental constraints } & $\begin{array}{l}\text { Accessing rights to land use through conquest or clearing } \\
\text { land }\end{array}$ & $\begin{array}{l}\text { Dynamics of occupation of still vacant land (pioneer } \\
\text { front in Africa and the Amazon) }\end{array}$ \\
\hline & \multirow[t]{3}{*}{ Sharing land-use rights between farmers } & Extensive pasturing \\
\hline \multirow{2}{*}{$\begin{array}{l}\text { Socio-institutional } \\
\text { constraints }\end{array}$} & & Community land-use rights (communal property) \\
\hline & & Land-use agreements between landowners and farmers \\
\hline $\begin{array}{c}\text { Environmental constraints } \\
+ \\
\text { Constraints linked to the } \\
\text { farm topology }\end{array}$ & Pooling of land-use rights to meet a common goal & Voluntary pooling of land use (collective land use) \\
\hline Economic constraints & $\begin{array}{l}\text { Delegation of land-use rights to agricultural management } \\
\text { companies }\end{array}$ & Use of agricultural contractors \\
\hline \multirow{6}{*}{$\begin{array}{l}\text { Measures or arrangements } \\
\text { proposed to farmers from a } \\
\text { given perspective and that } \\
\text { directly or indirectly impact } \\
\text { land use and land-use } \\
\text { rights }\end{array}$} & \multirow{5}{*}{$\begin{array}{l}\text { Policy instruments that impact user rights through } \\
\text { regulation }\end{array}$} & Environmental zonings \\
\hline & & Real Environmental Obligations (REOs) \\
\hline & & Rural Environmental Leases / land trust) \\
\hline & & Ecological compensation through supply \\
\hline & & \begin{tabular}{|l|} 
Land consolidation \\
\end{tabular} \\
\hline & $\begin{array}{l}\text { Policies instruments that change the structure of the land } \\
\text { tenure organizations }\end{array}$ & Land reform/expropriation \\
\hline
\end{tabular}




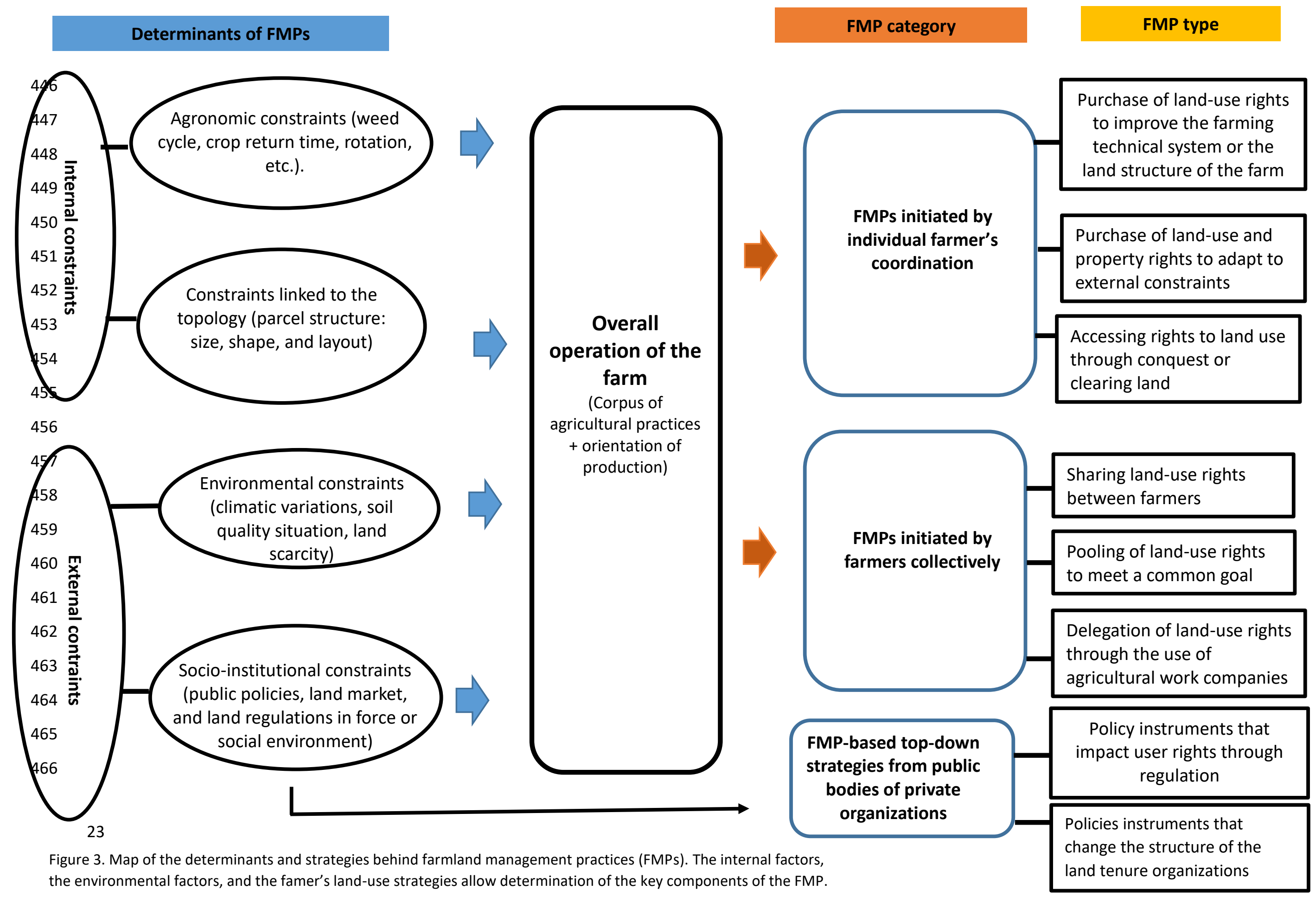




\subsection{There are possible environmental consequences of FMPs but in-depth studies are needed} The FMP typology that we presented in Section 4.2 highlights its diversity and accounts for the reasoning, based on the agronomic realities, of the choices made of actors involved in FMPs. Questions arise about the environmental impacts that may be associated with these choices. In this section, we discuss the general environmental impacts of FMPs.

\subsubsection{The major environmental consequences of FMPs identified in our literature search}

Only 25 papers out of 110 that we included referred to the environmental consequences of agricultural FMPs. Although this is not a substantial number of papers, we conclude from our study of them that FMPs may have considerable impacts on biodiversity, landscape, soil resources and water quality on a regional scale, both positive and negative.

\section{a) Environmental consequences of FMPs related to bottom-up strategies (local farmers' initiatives)}

Bottom-up FMPs are based on local farmers' choices, and these may modify the structure of the landscape and affect the environment. Particularly important factors in the agricultural pressure imposed on the environment by FMPs are strategies that modify the organization of plots and the cropping systems implemented (Leteinturier et al. 2006; Tscharntke et al. 2005; Chopin et al. 2017). For instance, Latruffe and Piet (2014), and Di Falco et al. (2010) noted that plot dispersal used by some farmers to address climate uncertainties appears to have positive environmental impacts as it allows a better match between crops and micro-local climatic conditions. Lipscomb and Prabakaran (2020) point out that colonization of the Amazon rainforest for agriculture by farmers who do not have land security is responsible for the destruction of forests and air pollution related to burning.

When the farmer strategizes to develop the topology of his farmland, he is likely to use such tools as grouping, exchanging, or temporarily renting plots. These allow him to modify the plot structure so that the plots become more homogenous. If the types of FMPs he chooses include structural modification of the farmstead, there may be significant modification of his crop rotation schedule 
493 (Barbottin et al. 2018). It may also result in the destruction of hedges (Saint-Cyr et al. 2019; Preux 494 2019), which can be problematic as hedges, along with bunches of trees, groves, copses, and forest 495 edges, are structuring and important elements of the rural landscape (Husson and Marochini 1997). Enlargement of plots can also favor devoting a much larger plot to a single crop than before the enlargement, which may lead to a decrease in crop diversity and increased vulnerability to pests and epidemics. At the landscape scale, this can result in loss of biodiversity, increased runoff, pollution of surface and ground water, and, in some cases, replacement of permanent grassland with plowed land (Preux 2019).

We also consider land-tenure insecurity, which is inherent in precarious land-tenure contracts. Although not a type of FMP, it is relevant here as it is proving to be a factor limiting farmers' willingness to invest in conservation of natural resources (Reid et al. 2000; Gao et al. 2012; P. Sklenicka 2016b; Hua Lu et al. 2019). For instance, unregulated changes in the property rights system may endanger the sustainability of the soil resources and favor overexploitation. A case study on extensive cattle breeding in Inner Mongolia (China) revealed that the privatization of pastures, which were previously collectively managed, could result in the depletion of natural and soil resources. As fencing expenses could not be implemented by all breeders, grassland in areas which remained open were overused ( $\mathrm{Li}$ et al. 2007).

Land-tenure insecurity also influences and differentiates farming operations. If farmers' plots are small and irregularly shaped, farmers are reluctant to adopt modern technologies or invest in soil improvement (Lucas et al. 2015). According to Keeley et al. (2019), the short duration of most leases

513 in the US, coupled with the failure of institutional instruments to regulate leases, constitute a major 514 constraint to the application of environmentally sound agricultural practices, such as agroforestry. In the same vein, Choumert and Phélinas (2015) estimate that in Argentina, farmers with precarious land leases are less inclined to adopt long-term land conservation and improvement practices than land owners. The latter, presumably due to their greater security, are more willing to practice soil conservation. 

private organizations

The consequences of FMPs initiated by public policy or private organizations on the environment were discussed more than the bottom-up strategies in the papers we examined.

The most common issue addressed in this group of papers was the environmental impacts of the type of FMP related to policy instruments that impact user rights through regulation. Land consolidation is one such policy. To summarize the opinions of several authors in general terms, it appears that land consolidation operations are intended to improve the spatial structure of agricultural areas and preserve the environment (Yu, Zeng, and Yu 2014; OREA et al. 2015; Strek 2018; Nilsson 2019). In China for instance, Li et al. (2017) studied the effects of a land transfer policy that was intended to regroup small private structures into larger ones, thereby facilitating mechanization in Jiangsu using a model. These researchers highlighted the fact that more pollution was caused by the increase from $13 \%$ to $51 \%$ use of diesel and the emission of engine exhaust. Yang et al. (2019) argue that changing the farmland structure from scattered small farms to large farms with consolidated parcels of land could reduce the environmental impacts of agricultural activities by reducing resource consumption. In the same vein, Zhang et al (2010) concluded that in Gaolong, China, land consolidation improved the agroecosystem services value, with the largest increase in nutrient cycling and the smallest in soil conservation. However, Lu et al. (2018) point out that land consolidation is of interest only at the level of plots, as it increases plot size without necessarily increasing the total area of the farm.

Researchers who are critical of these policies point out that the expansion of plots through land consolidation results in decreased in crop diversity, making the farm more vulnerable to epidemics and at increased risk for crop failure due to local natural disasters, such as heavy rains, hail, and floods (Husson and Marochini 1997; Kurylo et al. 2017; Gedefaw et al. 2019). In addition, changes in parcel structures may influence the choice of production systems (Pauchard et al. 2016). 
543 Other public policy instruments that impact user rights through regulations that may have

544 environmental consequences are agri-environment programs, such as those implemented in many

545 European countries. In Switzerland, farmers were required to maintain $7 \%$ of their useful agricultural

546 area as biodiversity promotion areas (BPA). This requirement increased butterfly species richness

547 (Zingg et al. 2019) .

548 The environmental footprint of land is also important in the policy instruments that change the 549 structure of the land-tenure organizations. Sallaku et al. (2016) suggested that the decision of the 550 Albanian government to redistribute land to each inhabitant was the cause of the environmental 551 changes and loss of biodiversity that was observed subsequently. Reid et al. (2000) point out that the 552 major changes observed in land use across Ethiopia were the result of the succession of land reforms 553 imposed between 1975 and 1985. Similarly, it has been argued that post-Mao land reform in China led 554 to irresponsible use of land resources, specifically, private financial investment in agriculture and 555 intensification of agriculture (Hu 1997). Subsequent overall degradation of the agro-ecological 556 environment was considered to be the result. Also in China, in the Yellow River Delta, Xu et al. (2014) 557 studied the factors that caused farmers to adopt organic fertilizers to reduce land salinization; they 558 also concluded that land tenure was closely linked to farmers' decisions. According to Liu et al. (2019), 559 the opportunity granted to Chinese farmers to rent land, allowing them to enlarge their plots, has 560 resulted in the application of some new farming technologies that permit them to use less fertilizer 561 and pesticide use in wheat and maize production. This should result in reduction in heavy metal 562 contamination of food and drinking water as well as fewer pesticide residues in food and the 563 environment.

\section{4.3.2. The need for in-depth studies on the environmental consequences of FMPs}

565 Among the 25 papers identified in the literature that referred to the environmental consequences of 566 agricultural FMPs, there is an uneven distribution of papers that dealt explicitly with the environmental 567 impacts of FMPs in relation to our typology, as detailed in Table 1. 
Various studies use environmental modeling to evaluate the impact of changes in farmland on non-

569 point water pollution and to assess the contribution of best management practices (BMPs) on reduction of the environmental impact of agriculture. For instance, in a study conducted in the ThreeGorges area in China, the authors identify BMPs favorable to water quality, such as contour farming and conservation tillage (Liu et al. 2015). In another study on the land-cover changes in the province of Shandong in China, Liu et al. found that increased grassland area had a positive impact on water quality (Liu et al. 2013). Sith et al. applied a watershed model in a study of the Southern Islands of the Japanese coral reef. They concluded that diversification of farmland use toward more pasture lowered water pollution by nitrate considerably (Sith et al. 2019). In these various studies of BMPS, the value of initiatives for collective action among farmers and advocacy for innovative local public policies is agricultural systems.

We also note that the available papers provide a weak basis at best for methodology designed to analyze the environmental impact of FMPs. Indeed, none of the papers related to local farmers' initiatives specify the methodology used to assess the environmental impacts of land practices, and conclusions seem to be based more on the authors' opinions than on a methodology designed for this purpose. This weakness is accompanied by a certain risk of bias. We argue, therefore, that methodological developments are needed to assess the environmental impact of FMPs based on local farmers' choices. Such a methodology may help identify FMPs that have higher environmental value and also help identify candidate FMPs that are likely to reduce the impact of agriculture on the environment. Future research should investigate these aspects.

\section{5. Conclusion}

Our purpose here was to review the relevant literature concerning the relationship between FMPs and the environment. We have focused on research that would help us develop a typology of FMPs and inform us on their environmental consequences. We hoped that by using references from both social 

are based on local farmers' initiatives to improve the functioning of their farms, and top-down practices, which are policies implemented by public bodies or private stakeholders.

Our survey highlights the fact that some FMPs may be innovative tools that reduce the pressure of agricultural activity on the environment. In contrast, others appear to have the undesired effects of increasing the pressure of agricultural activity on natural and semi-natural habitats, thereby threatening biodiversity and ecosystems. Additionally, some FMPs aim primarily to describe what is done rather than how it could be done best or have an environmental purpose, as is the case with BMPs.

Overall, our study underscores the need to consider both property rights and technical decision making in assessing FMPs. Exploring the environmental aspects of FMPs may be an interesting and valuable area for research as part of the current movement to reduce the environmental impacts of agricultural activities.

\section{Limits of this study}

Our definition of FMP allows us to focus on the relationship between property rights and environmental impact. However, because of this narrow definition, we have excluded studies related to land use without a change in rights, even though there is considerable literature that addresses the environmental consequences of changes in agricultural land use. Thus, research dealing with the link between land abandonment and the environment was excluded from our study.

Another limitation of the study is the lack of in-depth statistical analysis. The exploratory nature of the article led us to work with complex data in terms of the objectives pursued and the different questions asked in each paper consulted. However, this article opens up interesting perspectives for future research insofar as it positions environmental aspects of FMP as a potential research object. 
Akram, Nida, Muhammad Waqar Akram, Hongshu Wang, and Ayesha Mehmood. 2019. 'Does Land Tenure Systems Affect Sustainable Agricultural Development?' Sustainability 11 (14): 3925. https://doi.org/10.3390/su11143925.

Alavoine-Mornas, Françoise, and Sabine Girard. 2016. 'Foncier agricole et enjeux environnementaux : de nouvelles tensions au niveau des exploitations agricoles pour la mise en œuvre de la Trame Verte'. Sciences Eaux Territoires Numéro 19 (2): 46-49.

Amblard, Laurence, and Jean-Philippe Colin. 2009. 'Reverse Tenancy in Romania: Actors' Rationales and Equity Outcomes'. Land Use Policy 26 (3): 828-36. https://doi.org/10.1016/j.landusepol.2008.10.008.

Anzalone, Guilhem, and François Purseigle. 2014. 'Délégation d'activités et Sous-Traitance : Au Service de La Transmission de l'exploitation Ou d'un Patrimoine ?' In L'agriculture En Famille : Travailler, Réinventer, Transmettre, edited by Gasselin Pierre, Choisis Jean-Philippe, Petit Sandrine, Purseigle François, and Zasser Sylvie. EDP Science. https://doi.org/10.1051/978-2-7598-1192-2.c018.

Asiama, K.O., R.M. Bennett, J.A. Zevenbergen, and A. Da Silva Mano. 2019. 'Responsible Consolidation of Customary Lands: A Framework for Land Reallocation'. Land Use Policy 83: 412-23. https://doi.org/10.1016/j.landusepol.2019.02.006.

Barataud, Fabienne, and Florence Hellec. 2015. 'L'outil foncier, une solution délicate pour protéger les captages d'eau potable'. Economie rurale $n^{\circ} 347$ (3): 3-20.

Barbottin, Aude, Clemence Bouty, and Philippe Martin. 2018. 'Using the French LPIS Database to Highlight Farm Area Dynamics: The Case Study of the Niort Plain'. Land Use Policy 73 (April): 281-89. https://doi.org/10.1016/j.landusepol.2018.02.012.

Bertrand, N. 2013. Terres Agricoles Périurbaines : Une Gouvernance Foncière En Construction. Update Sciences \& Technologies. Versailles: Editions Quae. https://www.dawsonera.com/abstract/9782759220151.

Bertrand, Nathalie, and Sylvie Duvillard. 2016. 'Intégration des enjeux environnementaux dans la gestion du foncier agricole : introduction'. Sciences Eaux Territoires Numéro 19 (2): 2-5.

Beyene, Atakilte, David Gibbon, and Mitiku Haile. 2006. 'Heterogeneity in Land Resources and Diversity in Farming Practices in Tigray, Ethiopia'. Agricultural Systems, Heterogeneity and Diversity in Less-Favoured Areas, 88 (1): 61-74. https://doi.org/10.1016/j.agsy.2005.06.004.

Binot, Aurélie, and Alain Karsenty. 2007. 'La question foncière, les ressources naturelles et l'environnement. Trois dimensions indissociables du développement dans le monde contemporain'. VertigO - la revue électronique en sciences de l'environnement, no. Hors-série 4 (November). https://doi.org/10.4000/vertigo.301.

Boinon, Jean-pierre. 2013. 'Analyse de l'expérience française de contrôle des structures'. Pour $\mathrm{N}^{\circ} 220$ (4): 237-45.

Buskirk, Josh Van, and Yvonne Willi. 2004. 'Enhancement of Farmland Biodiversity within Set-Aside Land'. Conservation Biology 18 (4): 987-94. https://doi.org/10.1111/j.15231739.2004.00359.x.

Calo, Adam, and Kathryn Teigen De Master. 2016. 'After the Incubator: Factors Impeding Land Access Along the Path from Farmworker to Proprietor'. Journal of Agriculture, Food Systems, and Community Development 6 (2): 111-27. https://doi.org/10.5304/jafscd.2016.062.018.

Chopin, Pierre, Jean-Marc Blazy, Loïc Guindé, Régis Tournebize, and Thierry Doré. 2017. 'A Novel Approach for Assessing the Contribution of Agricultural Systems to the Sustainable Development of Regions with Multi-Scale Indicators: Application to Guadeloupe'. Land Use Policy 62 (March): 132-42. https://doi.org/10.1016/j.landusepol.2016.12.021.

Choumert, J., and P. Phélinas. 2015. 'Determinants of Agricultural Land Values in Argentina'. Ecological Economics 110: 134-40. https://doi.org/10.1016/j.ecolecon.2014.12.024.

Clément, Camille, Coline Perrin, and Christophe-Toussaint Soulard. 2019. 'Les arrangements pour l'accès au foncier agricole périurbain. L'exemple de Montpellier'. Développement durable et 
territoires. Économie, géographie, politique, droit, sociologie, no. Vol. 10, n³ (December). https://doi.org/10.4000/developpementdurable.15933.

Cochet, H. 2008. 'Le modèle de l'exploitation agricole familiale à la française a longtemps été basé sur la réunion entre les mêmes mains de la terre, du capital et de la force de travail. Après avoir fait ses preuves au cours des cinquante dernières années, ce modèle est aujourd'hui contesté par une partie de la profession agricole, appuyée par la dernière loi d'orientation agricole. Comment va-t-il évoluer ?', 7.

Colin, Jean-Philippe, and Garbin Tarouth. 2017. 'Les élites urbaines comme nouveaux acteurs du marché foncier en Côte d'Ivoire'. Géographie, économie, société 19 (3): 331-55. https://doi.org/10.3166/ges.19.2017.0016.

Daniels, Thomas L. 2020. 'Assessing the Performance of Farmland Preservation in America's Farmland Preservation Heartland: A Policy Review'. Society \& Natural Resources 33 (6): 75868.

Davis, Adam S., Jason D. Hill, Craig A. Chase, Ann M. Johanns, and Matt Liebman. 2012. 'Increasing Cropping System Diversity Balances Productivity, Profitability and Environmental Health'. PLOS ONE 7 (10): e47149. https://doi.org/10.1371/journal.pone.0047149.

Deaton, B.J., C. Lawley, and K. Nadella. 2018. 'Renters, Landlords, and Farmland Stewardship'. Agricultural Economics (United Kingdom) 49 (4): 521-31. https://doi.org/10.1111/agec.12433.

Di Falco, Salvatore, Ivan Penov, Aleksi Aleksiev, and Tom M. van Rensburg. 2010. 'Agrobiodiversity, Farm Profits and Land Fragmentation: Evidence from Bulgaria'. Land Use Policy 27 (3): $763-$ 71. https://doi.org/10.1016/j.landusepol.2009.10.007.

Doré, Thierry, Philippe Martin, Marianne Le Bail, Bertrand Ney, and Jean Roger-Estrade. 2006. L'agronomie aujourd'hui. Editions Quae.

Dounias, Isabelle. 1998. 'Modèles d'action et organisation du travail pour la culture cotonnière : cas des exploitations agricoles du bassin de la Bénoué au Nord Cameroun'. http://agris.fao.org/agris-search/search.do?recordID=FR2019102949.

Etrillard, Claire, and Michel Pech. 2015. 'Mesures de compensation écologique : risques ou opportunités pour le foncier agricole en France ?' [VertigO] La revue électronique en sciences de l'environnement 15 (2). http://www.erudit.org/en/journals/vertigo/2015-v15-n2vertigo02433/1035834ar/abstract/.

Foley, Jonathan A., Navin Ramankutty, Kate A. Brauman, Emily S. Cassidy, James S. Gerber, Matt Johnston, Nathaniel D. Mueller, et al. 2011. 'Solutions for a Cultivated Planet'. Nature 478 (7369): 337-42. https://doi.org/10.1038/nature10452.

Francart, C., and J.M. Pivot. 1998. 'Incidences de La Structure Parcellaire Sur Le Fonctionnement Des Exploitations Agricoles En Régions de Bocage'. Ingénieries Eau-Agriculture-Territoires, no. 14: 41-54.

Gao, Liangliang, Jikun Huang, and Scott Rozelle. 2012. 'Rental Markets for Cultivated Land and Agricultural Investments in China'. Agricultural Economics 43 (4): 391-403. https://doi.org/10.1111/j.1574-0862.2012.00591.x.

Gedefaw, A.A., C. Atzberger, W. Seher, and R. Mansberger. 2019. 'Farmers Willingness to Participate in Voluntary Land Consolidation in Gozamin District, Ethiopia'. Land 8 (10). https://doi.org/10.3390/land8100148.

Gerber, Jean-David, Thomas Hartmann, and Andreas Hengstermann. 2018. Instruments of Land Policy: Dealing with Scarcity of Land. Routledge.

Grammatikopoulou, I., S. Myyrä, and E. Pouta. 2013. 'The Proximity of a Field Plot and Land-Use Choice: Implications for Land Consolidation'. Journal of Land Use Science 8 (4): 383-402. https://doi.org/10.1080/1747423X.2012.675362.

Gueringer, Alain. 2019. 'L'articulation entre propriété et usage des terres agricoles : application au cas de Pise (Toscane)'. Développement durable et territoires. Économie, géographie, politique, droit, sociologie, no. Vol. 10, $n^{\circ} 3$ (December). https://doi.org/10.4000/developpementdurable.15060. 
Hagen-Zanker, Jessica, and Richard Mallett. 2013. 'How to Do a Rigorous, Evidence- Focused Literature Review in International Development', 27.

Holtslag-Broekhof, S. M., R. Beunen, R. van Marwijk, and J. S. C. Wiskerke. 2014. '“Let's Try to Get the Best out of It" Understanding Land Transactions during Land Use Change'. Land Use Policy 41 (November): 561-70. https://doi.org/10.1016/j.landusepol.2014.04.016.

Horst, Megan. 2019. 'Changes in Farmland Ownership in Oregon, USA'. Land 8 (3): 39. https://doi.org/10.3390/land8030039.

Hu, W. 1997. 'Household Land Tenure Reform in China: Its Impact on Farming Land Use and AgroEnvironment'. Land Use Policy 14 (3): 175-86. https://doi.org/10.1016/S02648377(97)00010-0.

Hu, Wei. 1997. 'Household Land Tenure Reform in China: Its Impact on Farming Land Use and AgroEnvironment'. Land Use Policy 14 (3): 175-86. https://doi.org/10.1016/S02648377(97)00010-0.

Husson, Jean-Pierre, and Eric Marochini. 1997. 'Les remembrements agricoles entre économie et écologie'. Norois 173 (1): 195-208. https://doi.org/10.3406/noroi.1997.6780.

Janovska, Vratislava, Petra Simova, Josef Vlasak, and Petr Sklenicka. 2017. 'Factors Affecting Farm Size on the European Level and the National Level of the Czech Republic'. Agricultural Economics-Zemedelska Ekonomika 63 (1): 1-12. https://doi.org/10.17221/317/2015AGRICECON.

Jarrige, Françoise, A.-M. Jouve, and Claude Napoleone. 2003. 'Et Si Le Capitalisme Patrimonial Foncier Changeait Nos Paysages Quotidiens?'

Jepsen, Martin Rudbeck, Tobias Kuemmerle, Daniel Müller, Karlheinz Erb, Peter H. Verburg, Helmut Haberl, Jens Peter Vesterager, et al. 2015. 'Transitions in European Land-Management Regimes between 1800 and 2010'. Land Use Policy 49 (December): 53-64. https://doi.org/10.1016/j.landusepol.2015.07.003.

Jun Li, Wen, Saleem H. Ali, and Qian Zhang. 2007. 'Property Rights and Grassland Degradation: A Study of the Xilingol Pasture, Inner Mongolia, China'. Journal of Environmental Management 85 (2): 461-70. https://doi.org/10.1016/j.jenvman.2006.10.010.

Keeley, Keefe O., Kevin J. Wolz, Kaitie Adams, Jeannine H. Richards, Erin Hannum, Severine von Tscharner Fleming, and Stephen J. Ventura. 2019a. 'Multi-Party Agroforestry: Emergent Approaches to Trees and Tenure on Farms in the Midwest USA'. Sustainability 11 (8): 2449. https://doi.org/10.3390/su11082449.

_- _ 2019b. 'Multi-Party Agroforestry: Emergent Approaches to Trees and Tenure on Farms in the Midwest USA'. Sustainability 11 (8): 2449. https://doi.org/10.3390/su11082449.

Kurylo, V., P. Pantaliienko, V. Bogdanets, and S. Ovcharuk. 2017. 'Land Fragmentation in Ukraine: Agricultural Land-Use Management and Jurisprudence Issues'. Problems and Perspectives in Management 15 (2): 102-9. https://doi.org/10.21511/ppm.15(2).2017.10.

Lamoureux, Ludovic. 2016. 'Politique d'acquisitions foncières et protection de la ressource en eau'. Sciences Eaux \& Territoires Numéro 19 (2): 38. https://doi.org/10.3917/set.019.0038.

Latruffe, L., and L. Piet. 2014a. 'Does Land Fragmentation Affect Farm Performance? A Case Study from Brittany, France'. Agricultural Systems 129: 68-80. https://doi.org/10.1016/j.agsy.2014.05.005.

- - - 2014b. 'Does Land Fragmentation Affect Farm Performance? A Case Study from Brittany, France'. Agricultural Systems 129: 68-80. https://doi.org/10.1016/j.agsy.2014.05.005.

Le Roy, Étienne. 1991. 'Introduction Générale En L'appropriation de La Terre En Afrique Noire: Manuel d'analyse de Décision et de Gestion Foncières Le Bris'. E., Le Roy, E., Mathieu, P., L'appropriation de La Terre En Afrique Noire, Paris, Karthala.

Leemans, R., and R. S. de Groot. 2003. Millennium Ecosystem Assessment: Ecosystems and Human Well-Being: A Framework for Assessment. Washington/Covelo/London: Island Press. https://library.wur.nl/WebQuery/wurpubs/326575. 
Léger-Bosch, C. 2019. 'Farmland Tenure and Transaction Costs: Public and Collectively Owned Land vs Conventional Coordination Mechanisms in France'. Canadian Journal of Agricultural Economics 67 (3): 283-301. https://doi.org/10.1111/cjag.12206.

Legras, Sophie, Elsa Martin, and Camille Régnier. 2016. 'Foncier agricole, qualité de l'eau et intervention publique'. Économie rurale. Agricultures, alimentations, territoires, no. 353-354 (June): 113-26. https://doi.org/10.4000/economierurale.4947.

Leteinturier, B., J. L. Herman, F. de Longueville, L. Quintin, and R. Oger. 2006. 'Adaptation of a Crop Sequence Indicator Based on a Land Parcel Management System'. Agriculture, Ecosystems \& Environment 112 (4): 324-34. https://doi.org/10.1016/j.agee.2005.07.011.

Li, Jing, Daniel Rodriguez, and Xueyu Tang. 2017. 'Effects of Land Lease Policy on Changes in Land Use, Mechanization and Agricultural Pollution'. Land Use Policy 64 (May): 405-13. https://doi.org/10.1016/j.landusepol.2017.03.008.

Lipscomb, Molly, and Niveditha Prabakaran. 2020. 'Property Rights and Deforestation: Evidence from the Terra Legal Land Reform in the Brazilian Amazon'. World Development 129 (May): 104854. https://doi.org/10.1016/j.worlddev.2019.104854.

Liu, Ying, Chenggang Wang, Zeng Tang, and Zhibiao Nan. 2019. 'Does Farmland Rental Contribute to Reduction of Agrochemical Use? A Case of Grain Production in Gansu Province, China'. Sustainability 11 (8): 2402. https://doi.org/10.3390/su11082402.

Lu, H., H. Xie, Y. He, Z. Wu, and X. Zhang. 2018. 'Assessing the Impacts of Land Fragmentation and Plot Size on Yields and Costs: A Translog Production Model and Cost Function Approach'. Agricultural Systems 161: 81-88. https://doi.org/10.1016/j.agsy.2018.01.001.

Lu, Hua, Peiwen Zhang, Hao Hu, Hualin Xie, Zhenning Yu, and Su Chen. 2019. 'Effect of the GrainGrowing Purpose and Farm Size on the Ability of Stable Land Property Rights to Encourage Farmers to Apply Organic Fertilizers'. Journal of Environmental Management 251 (December): 109621. https://doi.org/10.1016/j.jenvman.2019.109621.

Lucas, Véronique, Pierre Gasselin, Franck Thomas, and Pierre-François Vaquié. 2015. 'Coopération agricole de production : quand l'activité agricole se distribue entre exploitation et action collective de proximité'. In L'agriculture en famille : travailler, réinventer, transmettre, edited by P. Gasselin, J.-P. Choisis, S. Petit, F. Purseigle, and S. Zasser, 201. EDP Sciences. https://doi.org/10.1051/978-2-7598-1192-2.c012.

Luis OREA, Jose A Perez, and David Roibas. 2015. 'Evaluating the Double Effect of Land Fragmentation on Technology Choice and Dairy Farm Productivity: A Latent Class Model Approach | Elsevier Enhanced Reader'. 2015. https://doi.org/10.1016/j.landusepol.2015.01.016.

Magnan, Andre. 2015. 'The Financialization of Agri-Food in Canada and Australia: Corporate Farmland and Farm Ownership in the Grains and Oilseed Sector'. Journal of Rural Studies 41 (October): 1-12. https://doi.org/10.1016/j.jrurstud.2015.06.007.

Marie, M., A. Bensaid, and D. Delahaye. 2009. 'Impact of Distance on Agricultural Practices and Landscapes Organization: Case Study of Dairy Farm Functioning in Western Europe'. CyberGeo 2009.

Melot, Romain. 2014. 'Droits de propriété et d'usage sur la terre. Une étude statistique des recours contentieux en matière de fermage'. Économie rurale. Agricultures, alimentations, territoires, no. 342 (July): 69-85. https://doi.org/10.4000/economierurale.4402.

Merenlender, A. M., L. Huntsinger, G. Guthey, and S. K. Fairfax. 2004. 'Land Trusts and Conservation Easements: Who Is Conserving What for Whom?' Conservation Biology 18 (1): 65-76. https://doi.org/10.1111/j.1523-1739.2004.00401.x.

Morardet, Sylvie. 1995. Pratiques et stratégies foncières des agriculteurs: Un outil d'analyse pour l'aménagement des zones fragiles. Quae.

Mottet, A, S. Ladet, N. Coqué, and A. Gibon. 2006. 'Agricultural Land-Use Change and Its Drivers in Mountain Landscapes: A Case Study in the Pyrenees'. Agriculture, Ecosystems and Environment 114 (2-4): 296-310. https://doi.org/10.1016/j.agee.2005.11.017. 
Nguyen, Geneviève, and François Purseigle. 2012. 'Les exploitations agricoles à l'épreuve de la firme. L'exemple de la Camargue'. Études rurales, no. 190 (January): 99-118. https://doi.org/10.4000/etudesrurales.9695.

Nilsson, P. 2019. 'The Role of Land Use Consolidation in Improving Crop Yields among Farm Households in Rwanda'. Journal of Development Studies 55 (8): 1726-40. https://doi.org/10.1080/00220388.2018.1520217.

PARKER, DOMINIC P. 2004. 'Land Trusts and the Choice to Conserve Land with Full Ownership or Conservation Easements'. Natural Resources Journal 44 (2): 483-518.

Pauchard, Laura, Philippe Madeline, and Maxime Marie. 2016. 'L'échange parcellaire : une nouvelle étape dans l'aménagement foncier de l'Ouest français'. Norois, no. 240 (November): 7-24. https://doi.org/10.4000/norois.5928.

Paulo Flores Ribeiro, José Lima Santos, Miguel N. Bugalho, Joana Santana, Luís Reino, Pedro Beja, and Francisco Moreira. 2013. 'Modelling Farming System Dynamics in High Nature Value Farmland under Policy Change | Elsevier Enhanced Reader'. 2013. https://doi.org/10.1016/j.agee.2013.11.002.

Pavel Ciaian, d'Artis Kancs, Kristine Van Herck, and Liesbet Vranken. 2012. 'Key Issues and Developments in Farmland Rental Markets in EU Member States and Candidate Countries'. CEPS (blog). 6 February 2012. https://www.ceps.eu/ceps-publications/key-issues-anddevelopments-farmland-rental-markets-eu-member-states-and-candidate/.

Poinsot, Yves, and Béatrice Faure. 2000. 'L'incidence des formes parcellaires sur l'évolution des espaces agricoles : des exemples gersois'. Revue géographique des Pyrénées et du Sud-Ouest. Sud-Ouest Européen 9 (1): 45-57.

Preux, Thibaut. 2019. 'From Farms Enlargment to the Bocage Landscape Dynamics : Comparative Analysis of the Contribution of the Farm Spatial Extension to Landscape Dynamics in Normandy'. Theses, Normandie Université, Université Caen Normandie. https://hal.archivesouvertes.fr/tel-02432779.

Reid, R. S., R. L. Kruska, N. Muthui, A. Taye, S. Wotton, C. J. Wilson, and W. Mulatu. 2000. 'Land-Use and Land-Cover Dynamics in Response to Changes in Climatic, Biological and Socio-Political Forces: The Case of Southwestern Ethiopia'. Landscape Ecology 15 (4): 339-55. https://doi.org/10.1023/A:1008177712995.

Ribeiro, Paulo F., José L. Santos, Joana Santana, Luís Reino, Pedro J. Leitão, Pedro Beja, and Francisco Moreira. 2016. 'Landscape Makers and Landscape Takers: Links between Farming Systems and Landscape Patterns along an Intensification Gradient'. Landscape Ecology 31 (4): 791803.

Rotz, S., E.D.G. Fraser, and R.C. Martin. 2019. 'Situating Tenure, Capital and Finance in Farmland Relations: Implications for Stewardship and Agroecological Health in Ontario, Canada'. Journal of Peasant Studies 46 (1): 142-64. https://doi.org/10.1080/03066150.2017.1351953.

Sabourin, Eric, Patrick Caron, and Pedro Carlos Gama. 1995. 'Enjeux fonciers et gestion des communs dans le Nordeste du Brésil ':, 23.

Saint-Cyr, Legrand D F, Hugo Storm, Thomas Heckelei, and Laurent Piet. 2019. 'Heterogeneous Impacts of Neighbouring Farm Size on the Decision to Exit: Evidence from Brittany'. European Review of Agricultural Economics 46 (2): 237-66. https://doi.org/10.1093/erae/jby029.

Sallaku, Fatbardh, Odeta Tota, Bujar Huqi, Etleva Jojic, Enkeleda Emiri, and Shkelqim Fortuzi. 2016. Impact of Macroeconomic Changes and Property Rights on Forest Degradation, Land Use, and Environmental Situation in Albania. Edited by G. Zhelezov. Cham: Springer International Publishing Ag.

Salsi, Angelo, João Pedro Silva, and Europäische Kommission, eds. 2010. LIFE Improving the Conservation Status of Species and Habitats: Habitats Directive Article 17 Report. LIFE Focus Nature. Luxembourg: Publ. Off. of the Europ. Union.

Sklenicka, P. 2016a. 'Classification of Farmland Ownership Fragmentation as a Cause of Land Degradation: A Review on Typology, Consequences, and Remedies'. Land Use Policy 57: 694701. https://doi.org/10.1016/j.landusepol.2016.06.032. 
- - . 2016b. 'Classification of Farmland Ownership Fragmentation as a Cause of Land Degradation: A Review on Typology, Consequences, and Remedies'. Land Use Policy 57: 694-701. https://doi.org/10.1016/j.landusepol.2016.06.032.

Sklenicka, Petr, Vratislava Janovska, Miroslav Salek, Josef Vlasak, and Kristina Molnarova. 2014. 'The Farmland Rental Paradox: Extreme Land Ownership Fragmentation as a New Form of Land Degradation'. Land Use Policy 38 (May): 587-93. https://doi.org/10.1016/j.landusepol.2014.01.006.

Sklenicka, Petr, Kristina Janeckova Molnarova, Miroslav Salek, Petra Simova, Josef Vlasak, Pavel Sekac, and Vratislava Janovska. 2015. 'Owner or Tenant: Who Adopts Better Soil Conservation Practices?' Land Use Policy 47 (September): 253-61. https://doi.org/10.1016/j.landusepol.2015.04.017.

Steinmann, Horst-Henning, and Eike Stefan Dobers. 2013. 'Spatio-Temporal Analysis of Crop Rotations and Crop Sequence Patterns in Northern Germany: Potential Implications on Plant Health and Crop Protection'. Journal of Plant Diseases and Protection 120 (2): 85-94. https://doi.org/10.1007/BF03356458.

Stoms, David M., Patrick A. Jantz, Frank W. Davis, and Gregory DeAngelo. 2009. 'Strategic Targeting of Agricultural Conservation Easements as a Growth Management Tool'. Land Use Policy 26 (4): 1149-61. https://doi.org/10.1016/j.landusepol.2009.02.004.

Strek, Z. 2018. 'Prioritization of Land Consolidation and Exchange Works in Villages of Eastern Poland Using Example of Frampol Commune'. In , 17:599-604. https://doi.org/10.22616/ERDev2018.17.N225.

Teijeiro, D., E. Corbelle Rico, J. Porta, J. Parapar, and R. Doallo. 2020. 'Optimizing Parcel Exchange among Landowners: A Soft Alternative to Land Consolidation'. Computers, Environment and Urban Systems 79. https://doi.org/10.1016/j.compenvurbsys.2019.101422.

Tscharntke, Teja, Alexandra M. Klein, Andreas Kruess, Ingolf Steffan-Dewenter, and Carsten Thies. 2005. 'Landscape Perspectives on Agricultural Intensification and Biodiversity - Ecosystem Service Management'. Ecology Letters 8 (8): 857-74. https://doi.org/10.1111/j.14610248.2005.00782.x.

Van Rensburg, Tom M., Eithne Murphy, and Paul Rocks. 2009. 'Commonage Land and Farmer Uptake of the Rural Environment Protection Scheme in Ireland'. Land Use Policy 26 (2): 345-55. https://doi.org/10.1016/j.landusepol.2008.04.002.

Wästfelt, A., and Q. Zhang. 2018. 'Keeping Agriculture Alive next to the City - The Functions of the Land Tenure Regime Nearby Gothenburg, Sweden'. Land Use Policy 78: 447-59. https://doi.org/10.1016/j.landusepol.2018.06.053.

Xu, H., X. Huang, T. Zhong, Z. Chen, and J. Yu. 2014. 'Chinese Land Policies and Farmers' Adoption of Organic Fertilizer for Saline Soils'. Land Use Policy 38: 541-49. https://doi.org/10.1016/j.landusepol.2013.12.018.

Yang, Mingyue, Shikui Dong, Quanming Dong, Pu Wang, Wenting Liu, and Xinyue Zhao. 2020. 'Cooperative Grassland Management Practices Promoted by Land Tenure System Transformation Benefit Social-Ecological Systems of Pastoralism on the Qinghai-Tibetan Plateau, China'. Journal of Environmental Management 261 (May): 110215. https://doi.org/10.1016/j.jenvman.2020.110215.

Yang, X., P. Sui, X. Zhang, H. Dai, P. Yan, C. Li, X. Wang, and Y. Chen. 2019. 'Environmental and Economic Consequences Analysis of Cropping Systems from Fragmented to Concentrated Farmland in the North China Plain Based on a Joint Use of Life Cycle Assessment, Emergy and Economic Analysis'. Journal of Environmental Management 251. https://doi.org/10.1016/j.jenvman.2019.109588.

Yang, Xin, Anlu Zhang, and Fan Zhang. 2019. 'Farmers' Heterogeneous Willingness to Pay for Farmland Non-Market Goods and Services on the Basis of a Mixed Logit Model-A Case Study of Wuhan, China'. International Journal of Environmental Research and Public Health 16 (20): 3876. https://doi.org/10.3390/ijerph16203876. 
Yu, Qiwu, Qun Zeng, and Guangming Yu. 2014. 'The Influence of Land Consolidation on Biomass and Ecological Environment'. Research Journal of Applied Sciences, Engineering and Technology 7 (17): 3656-62. https://doi.org/10.19026/rjaset.7.719.

Zhang, Z., J.-Q. Gao, and C.-F. Wei. 2010. 'Changes of Agroecosystem Services Value under Effects of Land Consolidation'. Chinese Journal of Applied Ecology 21 (3): 723-33.

Zingg, Silvia, Eva Ritschard, Raphael Arlettaz, and Jean-Yves Humbert. 2019. 'Increasing the Proportion and Quality of Land under Agri-Environment Schemes Promotes Birds and Butterflies at the Landscape Scale'. Biological Conservation 231 (March): 39-48. https://doi.org/10.1016/j.biocon.2018.12.022. 